\title{
PENGUATAN PENGETAHUAN KEWARGANEGARAAN (CIVIC KNOWLEDGE) SEBAGAI UPAYA MENINGKATKAN PENDIDIKAN POLITIK (Studi di SMAN 1 Cikalong Wetan)
}

\author{
Yusuf Faisal Ali ${ }^{1}$, Rossa Nopany ${ }^{2}$, Aprillio Poppy Belladonna ${ }^{3}$ \\ ${ }^{123}$ Pendidikan Pancasila dan Kewarganegaraan, STKIP Pasundan Cimahi, Indonesia \\ email: yusuffaisalali2016@gmail.com
}

\begin{abstract}
Abstrak
Penelitian ini bertujuan untuk mendeskripsikan: 1) Upaya guru PPKn dalam menginternalisasi pendidikan politik melalui pembelajaran Pendidikan Kewarganegaraan di SMAN 1 Cikalong Wetan, 2) Hambatanhambatan yang dihadapi guru PPKn dalam menginternalisasi pendidikan politik melalui pembelajaran Pendidikan Kewarganegaraan di SMAN 1 Cikalong Wetan, dan 3) Solusi yang dilakukan guru PPKn untuk menghadapi hambatan-hambatan dalam menginternalisasi pendidikan politik melalui pembelajaran kewarganegaraan di SMAN 1 Cikalong Wetan. Jenis penelitian ini adalah deskriptif kualitatif.Subjek penelitian ini yaitu guru PPKn SMAN 1 Cikalong Wetan dan peserta didik. Pengumpulan data dilakukan dengan wawancara, observasi, dan dokumentasi. Hasil penelitian menunjukkan: 1) Upaya guru PPKn dalam menginternalisasi pendidikan politik melalui pembelajaran Pendidikan Kewarganegaraan di SMAN 1 Cikalong Wetan dengan cara memberikan praktek seperti simulasi pemilihan umum, peserta didik mengikuti praktek tersebut agar mereka tahu bagaimana cara-cara atau langkah-langkah saat pemilihan berlangsung dan peserta didik berpartisipasi aktif dalam pemilihan. 2) Hambatan-hambatan yang dihadapi guru PPKn dalam menginternalisasi pendidikan politik melalui pembelajaran Pendidikan Kewarganegaraan di SMAN 1 Cikalong Wetan mencakup kendala internal dan eksternal. 4) Solusi yang dilakukan guru PPKn untuk menghadapi hambatan-hambatan dalam menginternalisasi pendidikan politik melalui pembelajaran kewarganegaraan di SMAN 1 Cikalong Wetan yakni dengan meningkatkan keteladan, meningkatkan efektivitas dan kreativitas, dan memberikan suatu pengertian.
\end{abstract}

Kata Kunci: Internalisasi, Pendidikan Politik, Pendidikan Kewarganegaraan

\begin{abstract}
This study aims to describe: 1) The efforts of PPKn teachers in internalizing political education through Citizenship Education learning at SMAN 1 Cikalong Wetan, 2) The obstacles that PPKn teachers face in internalizing political education through Citizenship Education learning at SMAN 1 Cikalong Wetan, and 3 ) The solution made by PPKn teachers to face obstacles in internalizing political education through civics learning at SMAN 1 Cikalong Wetan. This type of research is descriptive qualitative. The subjects of this research are the PPKn teachers of SMAN 1 Cikalong Wetan and the students. Data collection was carried out by interview, observation, and documentation. The results showed: 1) The efforts of PPKn teachers in internalizing political education through Citizenship Education learning at SMAN 1 Cikalong Wetan by providing practices such as general election simulations, students follow these practices so that they know how to take place or steps during the election. and students participate actively in the election. 2) The obstacles faced by PPKn teachers in internalizing political education through Citizenship Education learning at SMAN 1 Cikalong Wetan include internal and external constraints. 4) The solution made by PPKn teachers to face obstacles in internalizing political education through civics learning at SMAN 1 Cikalong Wetan is by increasing exemplary, increasing effectiveness and creativity, and providing an understanding.
\end{abstract}

Keywords: Internalization, Political Education, Citizenship Education

\section{PENDAHULUAN}

Era Orde Baru menyisakan permasalahan yang begitu mendalam bagi bangsa Indonesia yaitu kurang terdidiknya mayoritas warga negara secara politik, akibat proses depolitisasi yang dilakukan secara sistematis oleh pemerintahan Orde Baru. Peningkatan pengetahuan dan kemampuan yang memadai tentang demokrasi, pembentukan sikap demokratis, kritis, berani melakukan kontrol dan menegakkan kebenaran dan keadilan, terasa kurang diperhatikan (Cholisin, 2004, hal. 55).Proses depolitisasi ini menyebabkan masyarakat cenderung bersifat pasif 
dan mudah untuk dimobilisasi oleh penguasa. Karakter warga negara yang pasif, tidak memiliki kemandirian, dan mudah dimobilisasi merupakan penghambat bagi terciptanya demokrasi di Indonesia (Rohmawati, 2012, hal. 1).

Sebuah negara demokrasi, semua rakyatnya harus paham dan mengerti tentang politik. Di era keterbukaan Indonesia sebagai negara demokrasi memberikan kebebasan seluas-luasnya kepada warga negara untuk berpolitik. Pemerintah harus melakukan pembinaan pendidikan politik kepada masyarakat secara serius. Pendidikan politik pada hakekatnya merupakan bagian dari pendidikan orang dewasa sebagai upaya edukatif yang intensional, disengaja dan sistematis untuk membentuk individu sadar politik dan mampu menjadi pelaku politik yang bertanggungjawab secara etis/moril dalam mencapai tujuan-tujuan politik (Kartono, 2009, hal. 64).

Pendidikan politik mempunyai peran penting dalam menciptakan bangsa yang melek politik serta membentuk karakter dan perilaku warga negara.pendidikan politik berpotensi untuk membentuk karakter, watak dan tanggung jawab warga negara sehingga dapat mencapai peradaban bangsa yang lebih maju (Sanusi, 2016, hal. 24).

Salah satu upaya untuk membina generasi muda di bidang politik, yaitu melalui pendidikan politik di sekolah, peserta didik akan memperoleh banyak pengetahuan tentang dunia politik dan peranan mereka di dalamnya. Sekolah memiliki peran penting dalam pembentukan sikap dan perilaku warga negara (Rohmawati, 2012, hal. 2). Oleh karena itu melalui pelajaran pendidikan kewarganegaraan peserta didik mendapat pengetahuan dan pemahaman politik disekolah. Memang dapat dikatakan bahwa semua mata pelajaran memiliki tujuan yang baik yaitu mendidik peserta didik agar dapat menjadi warga negara sesuai harapan. Namun pada dasarnya mata pelajaran yang secara khusus mendidik siswa untuk menjadi warga negara yang baik (to be good citizenship) dibebankan kepada pendidikan kewarganegaraan karena materi yang termuat didalamnya banyak mengangkat tentang pendidikan politik.

Di sekolah, mata pelajaran yang berkaitan dengan pendidikan politik adalah Pendidikan Pancasila dan Kewarganegaraan yang berisi tiga kompetensi pokok PPKn. Pertama, pengetahuan kewarganegaraan (civic knowledge). Kedua, keterampilan kewarganegaraan (civic skills). Ketiga, nilai-nilai kewarganegaraan (civic disposition) (Branson, 1999, hal. 4). Peserta didik banyak belajar pengetahuan, nilai, sikap, dan perilaku politik secara eksplit, terutama melalui mata pelajaran PPKn, anak diajarkan mengenai hak, dan kewajiban sebagai warga negara, sistem politik, otonomi daerah, partai poitik, budaya politik, dan sebagainya. Melalui pelajaran pendidikan kewarganegaraan ini anak diharapkan pada gilirannya dapat berpartisipasi aktif dalam kehidupan berbangsa dan negaranya (Wahyuningsih, 2013, hlm. 11). 
PPKn merupakan mata pelajaran yang memiliki misi sebagai pendidikan politik. Soedijarto dalam (Cholisin, 2010, hal. 2)mengartikan bahwa PPKn sebagai pendidikan politik bertujuan untuk mengembangkan warga negara yang baik, yaitu warga negara yang ikut berpartisipasi secara aktif dan bertanggungjawab dalam kehidupan berbangsa dan bernegara.

Namun kenyataannya, perilaku peserta didik sampai saat ini belum mencerminkan sikap dan perilaku yang demokratis. Ini berarti bahwa pendidikan politik selama ini belum berhasil dalam mengembangkan budaya demokratis.

Untuk mengetahui secara lebih mendalam mengenai peran guru PPKn dalam menginternalisasi pendidikan politik melalui pembelajaran pendidikan kewarganegaraan makapenelitian ini berusaha mendeskripsikan bagaimana;: 1)Upaya guru PPKn dalam menginternalisasi pendidikan politik melalui pembelajaran Pendidikan Kewarganegaraan di SMAN 1 Cikalong Wetan, 2) Hambatan-hambatan yang dihadapi guru PPKn dalam menginternalisasi pendidikan politik melalui pembelajaran Pendidikan Kewarganegaraan di SMAN 1 Cikalong Wetan, dan 3) Solusi yang dilakukan guru PPKn untuk menghadapi hambatan-hambatan dalam menginternalisasi pendidikan politik melalui pembelajaran kewarganegaraan di SMAN 1 Cikalong Wetan.

\section{METODE}

Penelitian ini menggunakan pendekatan kualitatif dengan metode deskriptif. Peneliti menggunakan tipe penelitian ini dengan maksud untuk mendeskripsikan secara mendalam fenomena serta gejala yang terjadi berdasarkan fakta yang berada di dalam suatu objek penelitian. Penelitian kualitatif dalam hal ini sejalan dengan yang dijelaskan oleh (Sugiyono, 2017, hal. 9) yang menjelaskan bahwa.

Metode penelitian kualitatif adalah metode penelitian yang berlandaskan pada filsafat postpositivesme, digunakan untuk meneliti pada kondisi objek yang alamiah, (sebagai lawannya adalah eksperimen) dimana penelitian adalah sebagai instrumen kunci, teknik pengumpulan data dilakukan secara triangulasi (gabungan), analisis data bersifat induktif atau kualitatif, dan hasil penelitian lebih menekankan makna dari pada generalisasi.

Berdasarkan pemaparan tersebut mengenai metode penelitian deskriptif analisis tersebut, maka pendekatan kualitatif menggunakan metode deskriptif analisis di anggap tepat untuk kajian penelitian yang peneliti lakukan, karena yang menjadi fokus penelitian ini adalah penguatan pengetahuan kewarganegaraan (civic knowledge) sebagai upaya meningkatkan pendidikan politik. 


\section{HASIL DAN PEMBAHASAN}

\section{Upaya Guru PKn dalam Menginternalisasi Pendidikan Politik Melalui Pembelajaran Pendidikan Kewarganegaraan di SMAN 1 Cikalong Wetan}

Guru PPKn dalam menginternalisasi pendidikan politik melalui pembelajaran pendidikan kewarganegaraan di SMAN 1 Cikalong Wetan adalah guru PPKn banyak melakukan hal-hal atau upaya-upaya khususnya seperti pemberian materi pembelajaran itu sendiri, lalu peserta didik diberikan tugas-tugas tentang pendidikan politik, hal ini dilakukan supaya peserta didik memiliki pemahaman terlebih dahulu tentang pentingnya pendidikan politik itu sendiri, setelah peserta didik memiliki pemahaman dalam diri individu-individu masing-masing barulah akan tumbuh suatu kesadaran yang akan mereka praktekan sendiri dalam lingkungannya, baik dalam lingkungan sekolah maupun lingkungan masyarakat. Sebagaimana yang dinyatakan menurut UU no. 14 tahun 2005 "Guru adalah pendidik profesional dengan tugas utama mendidik, mengajar, membimbing, mengarahkan, melatih, menilai, dan mengevaluasi peserta didik pada pendidikan anak usia dini jalur pendidikan formal, pendidikan dasar, dan pendidikan menengah.

Adapun tugas guru dalam proses pendidikan politik, yaitu sebagai pemegang dan penyampai nilai-nilai serta pandangan-pandangan tentang pendidikan politik, dan sebagai kreator dan manipulator budaya belajar, karena pada kenyataannya budaya atau kebiasaan belajar anak di kelas secara tidak langsung akan menimbulkan akibat politik. Tugas mendidik guru berkaitan dengan transformasi nilai dan pembentukan pribadi, sedangkan tugas mengajar berkaitan dengan transformasi pengetahuan dan keterampilan kepada peserta didik.Sebagaimana pendapat tersebut sesuai dengan yang dinyatakanUndang-Undang Nomor 14 Tahun 2005 tentang guru dan dosen pasal 20, maka tugas guru adalah:

a) Merencanakan pembelajaran, melaksanakan proses pembelajaran yang bermutu, serta menilai dan mengevaluasi hasil pembelajaran.

b) Meningkatkan dan mengembangkan kualifikasi akademik dan kompetensi secara berkelanjutan sejalan dengan perkembangan ilmu pengetahuan, teknologi dan seni.

c) Memelihara dan memupuk persatuan dan kesatuan bangsa. Guru mempunyai tanggung jawab, yang dimana tanggung jawabnya tidak hanya menyampaikan ide-ide, akan tetapi guru juga menjadi suatu wakil dari suatu cara hidup yang kreatif, suatu simbol kedamaian dan ketenangan dalam suatu dunia yang dicemaskan dan aniaya. Oleh karena itu, guru merupakan penjaga peradaban dan pelindung kemajuan (Siswoyo, 2007, hal. 133).

Upaya guru PPKn dalam menginternalisasi pendidikan politik yaitu dengan cara memberikan praktek seperti simulasi pemilihan umum, peserta didik mengikuti praktek tersebut agar mereka tahu bagaimana cara-cara atau langkah-langkah saat pemilihan berlangsung dan peserta didik berpartisipasi aktif dalam pemilihan. Selanjutnya dengan cara memberikan 
penguatan materi-materi PPKn yangberkaitan dengan pendidikanpolitik dan menggunakan metode yang mengarahkan kepada pendidikan politik.

\section{Hambatan-hambatan yang dihadapi Guru PPKn dalam Menginternalisasi Pendidikan Politik melalui Pembelajaran Pendidikan Kewarganegaraan di SMAN 1 Cikalong Wetan}

a) Hambatan Internal

Guru PPKn menemukan hambatan yakni kesulitan dalam memberikan keteladanan kepada peserta didik dalam pelaksanaan pengembangan pendidikan politik. Kesulitan yang dialami guru PPKn tersebut muncul salah satunya dari kondisi negara yang tidak stabil, sedangkan menurut (Cholisin, 2010, hal. 2)guru PPKn dapat dikatakan sebagai guru profesional apabila guru tersebut memiliki kompetensi diantaranya memahami materi, struktur, konsep, dan pola pikir keilmuan yang mendukung mata pelajaran PPKn, memahami substansi PPKn yang meliputi pengetahuan kewarganegaraan (civic knowledge), nilai dan sikap kewarganegaraan (civic disposition), dan keterampilan kewarganegaraan (civic skills), dan dapat menunjukkan manfaat mata pelajaran PPKn. Dengan demikian, adanya inspirasi atau teladan sangat mempengaruhi perkembangan peserta didik dalam menginternalisasikan nilai-nilai politik telah ditransformasikan melalui mata pelajaran PPKn.

b) Kendala Eksternal

1) Terbatasnya Alokasi Waktu Pembelajaran

Materi matapelajaran PPKn yang cukup banyak dengan alokasi waktu pembelajaran yang hanya 2 jam pelajaran ( 2 x 45 menit) setiap minggu untuk tingkat menengah atas menjadi hambatan dalam pelaksanaan pengembangan pendidikan politik pada kegiatan belajar mengajar. Hal tersebut sebagaimana yang terlampir dalam Lampiran Peraturan Menteri Pendidikan dan KebudayaanNomor 22 Tahun 2016 tentang Standar Proses Pendidikan Dasar dan Menengah menyebutkan bahwa untuk alokasi waktu pembelajaran jam tatap muka jenjang SMA/MA adalah 45 menit. Jika setiap minggunya 2 jam pelajaran maka jumlah waktu pembelajaran hanya 90 menit. Alokasi waktu pembelajaran tersebut dirasa kurang dengan materi mata pelajaran PPKn yang sebagaimana diungkapkan oleh Cholisin (2010, hlm. 8-9) bahwa PPKn sebagai pendidikan politik formal membawa konsekuensi materinya tidak hanya berkaitan secara eksplisit dengan nilai-nilai politik tetapi juga terstruktur secara ilmiah dan sistematis dalam pengetahuan kewarganegaraan (civic knowledge), keterampilan 
kewarganegaraan (civic skills yang meliputi intellectual skillsdan participation skills), dan karakter kewarganegaraan (civic dispositions).

2) Pengaruh Negatif dari Luar

Adanya pengaruh negatif dari luar yang terjadi di masyarakat merupakan salah satu hambatan yang dihadapi guru PPKn dalam pengembangan pendidikan politikpada kegiatan belajar mengajar dalam kelas. Hal tersebut dicontohkan dengan kasus diantaranya, banyak pejabat negara yang melakukan korupsi, penyelewengan jabatan, dan sebagainya tentu saja mempengaruhi pemikiran peserta didik terhadap pemahamannya mengenai politik, hukum, dan moral yang diajarkan di sekolah. Kemudian Cholisin (2000, hlm. 8) mengatakan bahwa dapat dikatakan bentuk sosialisasi politik langsung apabila seseorang menerima atau mempelajari nilai-nilai informasi, sikap, pandangan-pandangan, keyakinan-keyakinan mengenai politik secara eksplisit. Adanya pengaruh negatif dari luar yang terjadi di masyarakat memberikan efek terhadap pemahaman peserta didik yang mana pemahaman yang diperoleh peserta didik tersebut seakan-akan timpa dengan apa yang telah ditransformasikan oleh guru PPKn melalui mata pelajaran PPKn.

c) Latar Belakang Peserta Didik yang Berbeda

Latar belakang peserta didik yang berbeda-beda juga menjadi hambatan yang dihadapi oleh guru PPKn, baik dari kondisi keluarga, teman bermain maupun lingkungan dimana ia berada. Latar belakang yang kurang mendukung terciptanya iklim politik dapat menghambat guru PPKn dalam mengembangkan pendidikan politik. Hal tersebut sebagaimana yangdiungkapkan oleh Cholisin (2000, hlm. 6) bahwa metode belajar politik yang dapat dimanfaatkan untuk menunjang pembelajaran politik melalui mata pelajaran PPKn salah satunya adalah imitasi, yakni metode belajar politik dengan metode meniru, baik oleh orang tua, muda, pandai yang mana modal dasarnya adalah adanya mobilisasi atau komunikasi, tanpa adanya kedua hal ini sulit untuk dilaksanakan. Contohnya, anak-anak pada umumnya memilih partai politik meniru pilihan orang tuanya. Hal ini berarti lingkungan keluarga maupun lingkungan dimana peserta didik berada mempengaruhi pengembangan pendidikan politik yang dikembangkan oleh guru PPKn.

3. Solusi yang dilakukan Guru PPKn untuk menghadapi hambatan-hambatan dalam menginternalisasi Pendidikan Politik melalui Pembelajaran Kewarganegaraan di SMAN 1 Cikalong Wetan

a) Cara Mengatasi Kendala Internal 
Seorang guru harus menjadi contoh bagi peserta didik. Sebagaimana pendapat yang dikemukakan oleh (Suparlan, 2006, hal. 33-34) yang mengatakan bahwa sebagai pendidik, guru lebih banyak sebagai sosok panutan, yang memiliki moral dan agama yang patut ditiru dan diteladani oleh siswa. Contoh dan keteladanan itu lebih merupakan aspek-aspek sikap dan perilaku, budi pekerti luhur, dan akhlak mulia, seperti jujur, tekun, mau belajar, amanah, sosial dan sopan santun terhadap sesama. Guru sebagai seorang teladan harus berusaha mengemas dan menjalankan nilai-nilai yang ditanamkan kepada peserta didik. Hal ini sejalan dengan pendapat Cholisin (2011, hlm. 19) bahwa guru hendaknya dapat menjadi contoh bagi peserta didik sebagai guru yang berkarakter. Maksudnya sikap dan tindakan guru menggambarkan karakter yang diinternalisasikan kepada peserta didik.

b) Cara Mengatasi Kendala Eksternal

1) Guru Meningkatkan Efektivitas dan Kreativitas dalam Pembelajaran

Alokasi waktu pembelajaran menjadi kendala yang dihadapi oleh guru PPKn dalam pengembangan pendidikan politik pada kegiatan belajar mengajar dalam kelas. Dalam mengatasi alokasi waktu pembelajaran mata pelajaran PPKn yang hanya 90 menit ( 2 x 45 menit) tersebut, guru PPKn berusaha meningkatkan efektivitas dan kreativitasnya dalam proses pembelajaran. Guru dituntut untuk mampu mengembangkan bahan ajar, metode, dan media pembelajaran yang mempermudah peserta didik untuk memahami dan mengerti materi yang diajarkan dengan alokasi waktu yang telah disediakan. Hal ini sebagaimana pendapat (Hamdayana, 2016, hal. 12)yang menyebutkan bahwa guru dalam pembelajaran harus memiliki kemampuan untuk memilih, menata, mengemas, meteri pembelajaran ke dalam cakupan dan kedalaman yang sesuai dengan sasaran kurikuler, serta memiliki kemampuan daya tangkap sehingga mudah di cerna oleh peserta didik. Dengan demikian proses pembelajaran menjadi menarik perhatian peserta didik dengan penjelasan yang lugas dan tidak berbelit-belit sehingga peserta didik dapat memahami materi dengan mudah.

2) Guru Memberikan Suatu Pengertian

Cara yang dapat dilakukan oleh guru PPKn dalam mengatasi hambatan terkait adanya pengaruh negatif dari luar dan latar belakang peserta didik yang berbeda-beda mempengaruhi proses pengembangan pendidikan politik pada kegiatan belajar mengajar dalan kelas adalah dengan memberikan suatu pengertian dan contoh-contoh yang mudah dipahami oleh peserta didik. Karena menurut Suparlan (2006, hlm. 33-34) guru sebagai pembimbing perlu memiliki kemampuan untuk dapat membimbing 
peserta didik, memberikan dorongan psikologis agar peserta didik dapat menepikan faktor-faktor internal dan faktor eksternal yang akan mengganggu proses pembelajaran di dalam, dan di luar sekolah, serta memberikan arah dan pembinaan karir peserta didik sesuai dengan bakat dan kemampuan peserta didik. Pengertian dan sikap saat ini tengah dibutuhkan dalam pembinaan terhadap peserta didik melihat kondisi peserta didik yang saat ini kurang dalam menginternalisasikan nilai-nilai baik yang didapatkan maka peran guru sebagai demonstrator dalam hal ini sangat dibutuhkan. Sebagaimana yang diungkapkan oleh (Sanjaya, 2008, hal. 281-290) bahwa peran guru sebagai demonstrator yakni guru berperan untuk mempertunjukan kepada peserta didik segala sesuatu yang membuat peserta didik lebih paham, mengerti setiap pesan yang disampaikan. Memberikan suatu pengertian dan sikap tentang sesuatu hal yang baik dan buruk tentu akan membuka pemahaman peserta didik sehingga akan membantu peserta didik mencapai tujuan yang diharapkan dalam pengembangan pendidikan politik.

\section{SIMPULAN}

1. Upaya guru PPKn dalam menginternalisasi pendidikan politik melalui pembelajaran Pendidikan Kewarganegaraan di SMAN 1 Cikalong Wetan dengan cara memberikan penguatan materi-materi PPKn yang berkaitan dengan pendidikan politik dan menggunakan metode yang mengarahkan kepada pendidikan politik.

2. Hambatan-hambatan yang dihadapi guru dalam menginternalisasi pendidikan politik melalui pembelajaran Pendidikan Kewarganegaraan di SMAN 1 Cikalong Wetan terbagi menjadi 2 bagian yaitu, secara internal dan eksternal. Secara internal yaitu guru mendapatkan kesulitan dalam memberikan teladan. Sedangkan secara eksternal disebabkan karena terbatasnya alokasi waktu pembelajaran, dan adanya pengaruh negatif terhadap peserta didik di luar sekolah berupa anggapan bahwa politik itu identik dengan korupsi dan menyalahgunakan kekuasaan.

3. Solusi yang dilakukan guru PPKn untuk menghadapi hambatan-hambatan dalam menginternalisasi pendidikan politik melalui pembelajaran kewarganegaraan di SMAN 1 Cikalong Wetan dikategorikan menjadi 2 bagian, yaitu secara internal dan eksternal. Adapun secara internal dilakukan dengan cara meningkatkan keteladanan dengan menjalankan nilai-nilai yang sudah diinternalisasi, meningkatkan efektivitas dan kreativitas dengan menggunakan metode dan media yang sesuai dengan tuntutan materi dan memberikan suatu pengertian dengan memberikan contoh-contoh yang mudah 
dipahami oleh peserta didik. Sedangkan secara eksternal dengan cara memberikan pemahaman yang tepat kepada peserta didik terkait dengan pendidikan politik.

\section{UCAPAN TERIMA KASIH}

Peneliti mengucapkan terimakasih kepada SMAN 1 Cikalong Wetan yang telah mengizinkan peneliti melakukan penelitian ini.

\section{DAFTAR PUSTAKA}

Branson. (1999). The Role of Civic Education. Calabasas: Center for Civic Education (CEE). .

Cholisin. (2010). Diktat Pendidikan Kewarganegaraan (Civic Education). Yogyakarta: UNY Press.

Cholisin. (2004). Pendidikan Kewarganegaraan . Yogyakarta: Fakultas Ilmu Sosial dan Ekonomi UNY.

Cholisin. (2010). Pendidikan Kewarganegaraan (Civic Education). Yogyakarta: UNY Press.

Hamdayana, J. (2016). Metodologi Pengajaran. Jakarta: PT Bumi Aksara.

Kartono, K. (2009). Pendidikan Politik. Bandung: Mandar Maju.

Rohmawati, R. (2012). Implementasi Pendidikan Politik dalam Pembelajaran Pendidikan Kewarganegaraan Guna Pengembangan Budaya Demokratis di SMA Negeri Se Kabupaten Bantul. Yogyakarta.

Sanjaya, W. (2008). Strategi Pembelajaran Berorientasi Standar Proses Pendidikan. Jakarta: Kencana Prenada Media Group.

Sanusi. (2016). Implementasi Pendidikan Politik dalam Membentuk Karakter Kepemimpinan Lintas Budaya pada Generasi Muda demi Mewujudkan Budaya Politik Pancasila. Yogyakarta: UNY.

Siswoyo, D. (2007). Ilmu Pendidikan. Yogyakarta: UNY Press.

Sugiyono. (2017). Metode Penelitian Kuantitatif Kualitatif R \& D . Bandung: Alfabeta.

Suparlan. (2006). Guru Sebagai Profesi. Yogyakarta: Andi Offset.

Undang-Undang Nomor 14 Tahun 2005. Guru dan Dosen pasal 20. Jakarta. 